\title{
EFFECTS OF EURASIAN SNOW COVER ON ATMOSPHERIC CIRCULATION IN THE NORTHERN HEMISPHERE
}

\section{(Abstract)}

by

Yuki Morinaga and Tetuzo Yasunari

(Institute of Geoscience, University of Tsukuba, Ibaraki 305, Japan)

Effects of Eurasian snow cover were first noted by Blanford (1884) who found an inverse relationship between summer monsoon rainfall over India and winter snow cover over the Himalayas. Hahn and Shukla (1976) confirmed it by using satellite-derived data and their work stimulated succeeding studies on the interaction between large-scale snow cover and atmosphere. Matson and Wiesnet (1981) showed that interannual variation of northern hemisphere snow cover is dominated by Eurasian snow cover, both showing similar trends and fluctuations during 1967-79. Recent studies (Barnett, 1988) also noted that Eurasian snow cover has a greater feedback potential than that of North America on hemispheric-scale climatic anomalies.

Though the importance has been thus recognized, not many studies have been done on the interaction between Eurasian snow cover and large-scale atmospheric circulation anomalies. Morinaga and Yasunari (1987) studied lag correlations between satellite-derived snow-cover extent over central Asia and the $500 \mathrm{mb}$-geopotential height field in the Northern Hemisphere (1967-84), and indicated that so-called Eurasian pattern (Wallace and Gutzler, 1981) in December brings large snow-cover extent in February; in turn, February snow cover has a considerable lingering effect on the atmosphere in April.

This study present further results on the time-lag teleconnections of the atmosphere associated with Eurasian snow-cover anomalies and their physical implications including the evaluation of snow-hydrological process.

\section{REFERENCES}

Barnett, T., U. Dumenil, E. Schlese, E. Roeckner, and M. Latif. 1989. The effect of Eurasian snow cover on regional and global climate variations. J. Atmos. Sci., 46, 661-685.

Blanford, H.F. 1884. On the connexion of the Himalayan snowfall with dry winds and seasons of drought in India. Proc. Roy. Soc. London, 37, 3-12.

Hahn, D.G. and J. Shukla. 1976. An apparent relationship between Eurasian snow cover and Indian monsoon rainfall. J. Atmos. Sci., 33, 2461-2462.

Matson, M. and D.R. Wiesnet. 1981. New data base for climate studies. Nature, 289, 451-456.

Morinaga, Y. and T. Yasunari. 1987. Interactions between the snow cover and the atmospheric circulations in the northern hemisphere. IAHS Publication No. 166, 73-78.

Wallace, J.M. and D.S. Gutzler. 1981. Teleconnections in the geopotential height field during the northern hemisphere winter. Mon Weather Rev., 109, 784-812.

\section{PARAMETERIZATION OF BOUNDARY CONDITIONS BETWEEN THE ATMOSPHERE AND CRYOSPHERE}

\section{(Abstract)}

by

E.M. Morris,

(British Antarctic Survey, Natural Environment Research Council, High Cross, Madingley Road, Cambridge CB3 OET, UK)

and

R.J. Harding

(Institute of Hydrology, Natural Environment Research Council, Maclean Building, Crowmarsh Gifford, Wallingford, Oxfordshire OX10 8BB, UK)

Parameterization of the boundary conditions between the atmosphere and cryosphere is an important part of the general problem of modelling climatic change. It is necessary to define the mass, momentum and energy exchanges at the ice/atmosphere interface in order (i) to use atmospheric global circulation models (AGCMs) to predict future climate and (ii) to use snow, glacier or ice-sheet models to predict the corresponding response of the cryosphere. The physics of the boundary processes are fairly well known; the difficulty lies in choosing the appropriate space and time scales for modelling and in understanding the changes in the effective values of the model parameters which may be produced by spatial and temporal averaging.

Sensible heat, water vapour and momentum are tranferred vertically in the boundary layer of the atmosphere by turbulent motion. Equations for these fluxes contain parameters, the so-called scaling lengths $\mathrm{zH}, \mathrm{ZE}$ and zo. Net radiation input to snow or ice is controlled by the albedo of the surface, $\alpha$. These four parameters play a major role in defining the boundary conditions between the atmosphere and cryosphere. It is normally assumed that their values are constants, determined by the characteristics of the snow or ice surface alone. For example, climate models may set $\mathrm{zH}=\mathrm{Ze}=\mathrm{z} 0=0.1 \mathrm{~mm}$ and $\alpha=0.9$ for smooth, fresh snow. However, in modelling practice it is often found that the effective values of the parameters, i.e. those values that give the best simulations, are also influenced by the level of variability in the meteorological conditions.

The authors have made intensive micro-meteorological studies in the firn area of the Hintereisferner, Ötztal Alpen (Austria), on a frozen lake near Finse, Hardangervidda (Norway), and in the south-west coastal region of Greenland. Data from these field sites will be used to investigate the sensitivity of effective values of the boundary condition parameters to the choice of time scale using the Institute of Hydrology Distributed Model (IHDM). 